\title{
Gamifikasi Upaya Menangkal Hoaks Terhadap Informasi Vaksinasi Covid-19 di Social Media dalam Scope Keluarga
}

\author{
Nugrahardi Ramadhani ${ }^{1,}{ }^{*}$ | Rabendra Yudistira Alamin ${ }^{1}$ | Nurina Orta Darmawati ${ }^{1}$ | Didit \\ Prasetyo $^{1}$ | Putri Dwitasari ${ }^{1}$ | Renny Pradina Kusumawardani ${ }^{1}$
}

\footnotetext{
${ }^{1}$ Departemen Desain Komunikasi Visual, Institut Teknologi Sepuluh Nopember, Surabaya, Indonesia
}

\section{Korespondensi}

*Nugrahardi Ramadhani, Departemen Desain Komunikasi Visual, Institut Teknologi Sepuluh Nopember, Surabaya, Indonesia. Alamat e-mail:

dhanisancok@its.ac.id

\author{
Alamat \\ Laboratorium Digital Creative Media, \\ Departemen Desain Komunikasi Visual, \\ Institut Teknologi Sepuluh Nopember, \\ Surabaya, Indonesia
}

\begin{abstract}
Abstrak
Setahun tepat pandemi covid-19 di tanah air ini diumumkan mulai menginfeksi 2 orang oleh Presiden Republik Indonesia, dan saat ini telah mencapai angka total 1,2 juta jiwa, artinya setiap bulannya kurang lebih 600.000 jiwa teridentifikasi covid19. Perjalanan perjuangan bangsa ini melawan covid menorehkan perjalanan cukup pelik, mulai dari naik turunnya laju sebaran virus corona itu sendiri, jatuh bangun pemerintah menahan laju sebaran covid-19, informasi-informasi misleading dan hoaks begitu deras di masyarakat sehingga pandemi ini menjadi susah tertangani. Hoaks merupakan informasi bohong atau bisa separuh tidak benar, kemudian ditambahkan informasi lain yang bisa mengaburkan informasi aslinya. Penanganan covid-19 ini tidak lepas dari edukasi yang baik dan benar, sehingga masyarakat paham tentang bahaya virus yang telah merengut jutaan jiwa di seluruh dunia ini. Munculnya hoaks salah satunya disebabkan kurang informasi dan informasi bohong atau tidak benar yang muncul secara sistematis. Negara kita telah masuk pada pembentukan herd immunity melalui vaksin covid-19, muncul pro dan kontra ditengah masyarakat menambah deret pekerjaan rumah pemerintah untuk meyakinkan masyarakat ikut serta dalam program pemerintah ini. Sosial media berperan penting dalam mewadahi pendapat-pendapat masyarakat dengan bebas, media-media nasional juga memberikan dukungan melalui akun-akun resminya, sehingga opini baik positif maupun negatif terbentuk liar. Pengabdian masyarakat ini menggunakan metode pembelajaran tentang hoaks vaksinasi sebagai media penyadaran masyarakat memakai gamifikasi yang diterapkan pada aplikasi berbasis web sebagai simulasi eduakasi dan literasi dalam scope kecil yakni keluarga.
\end{abstract}

\section{Kata Kunci:}

Gamifikasi, Pandemi, Hoaks, Keluarga, Media Sosial. 


\section{1 | PENDAHULUAN}

Pandemi belum berakhir, gelombang serbuan virus corona di berbagai negara memiliki riwayat yang berbeda-beda sesuai dengan karakter masing-masing penduduk. Cakupan program vaksinasi di Indonesia sudah melampaui target, namun hal ini membuat rakyat menjadi abai akan protokol kesehatan, padahal vaksin bukan jaminan, namun hanya menurunkan resiko gejala dari paparan virus. Kemudian disisi lain disinformasi dan serbuan konten hoaks setiap harinya dapat kita jumpai di berbagai media, terutama sosial media, dampaknya adalah mengaburkan pemahaman masyarakat akan pentingnya dan resiko program pemerintah berupa vaksinasi Covid-19. Tidak jarang, informasi yang belum jelas kebenarannya menjadi dasar bagi mereka untuk menentukan keputusan besar dalam hidup, terutama dalam lingkup keluarga. Bagi seorang guru SD, kehilangan pekerjaan bukan masalah ketimbang harus merelakan vaksin Covid-19 disuntikkan ke dalam tubuhnya. Sebab, tidak ada jaminan bahwa produk yang baru dikembangkan selama setahun itu aman dan tidak akan mencelakakan dirinya di masa depan. Fenomena rendahnya literasi juga terjadi pada tenaga-tenaga pendidik tingkat perguruan tinggi, mereka ada yang menganggap vaksin tersebut mengandung bahan-bahan berbahaya.

Sosiolog UIN Syarif Hidayatullah, Iim Halimatussa'diah, menilai, hoaks merupakan tantangan terbesar bagi masyarakat dalam mengambil keputusan di era informasi yang cukup deras ini. Saat ini, masyarakat tidak kekurangan informasi, tetapi justru berlimpah ruah. Namun, mereka cenderung memilih hanya yang sesuai dengan keyakinannya [1] "Hoaks jadi mudah dipercaya karena tidak dikroscek dengan informasi lainnya," kata Iim. Dalam konteks narasi antivaksin, kata Iim, hoaks seperti "bumbu penyedap" yang memperkuat keraguan karena faktor agama dan ketidakpercayaan terhadap pemerintah. Hal ini juga dipicu oleh sisa-sisa sentimen pilpres dan pilkada beberapa tahun yang lalu, mengakar hingga ke akar rumput menjadi pemahamanpemahaman sendiri [2]. Oleh karena itu, pemerintah perlu menunjukkan transparansi dalam program vaksinasi dan berkolaborasi dengan banyak pihak untuk menggencarkan kampanye tentang manfaat vaksin Covid-19. Apalagi, banyak pihak meragukan kemanjuran vaksin Sinovac, vaksin buatan perusahaan asal China, Sinovac Biotech Ltd, yang pertama dibeli pemerintah untuk masyarakat Indonesia. Berdasarkan hasil uji klinis, Badan Pengawas Obat dan Makanan (BPOM) telah menerbitkan izin penggunaan darurat dengan tingkat efikasi atau kemanjuran 65,3 persen. Meski sudah melewati ambang batas keamanan yang ditetapkan Organisasi Kesehatan Dunia (WHO), yaitu 50 persen, tingkat efikasi itu lebih rendah dari hasil uji vaksin lain di beberapa negara. Pada gambar 1 di atas dapat kita baca laju kecepatan hoaks vaksin Covid-19 cukup bertambah drastis, setiap bulannya

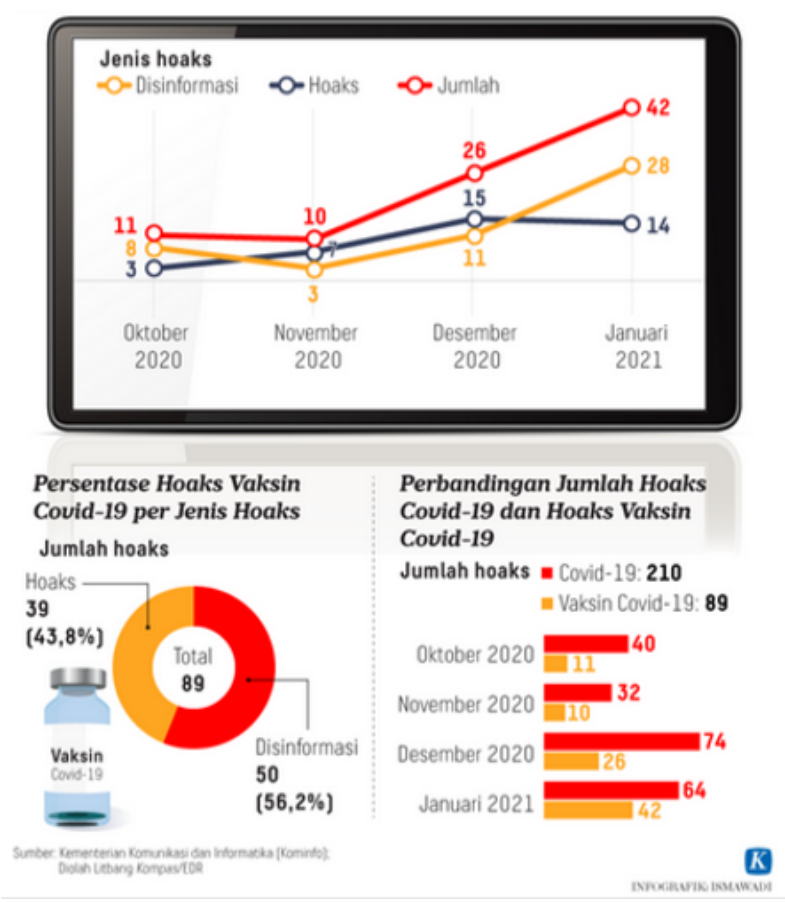

Gambar 1 Hoaks Vaksin Covid-19 yang melanda Indonesia (sumber : Kompas Media) 
pada empat bulan terakhir antara oktober 2020 hingga januari 2021.

Presiden Republik Indonesia, Joko Widodo, dalam kesempatannya pada rapat koordinasi penanggulangan bencana tahun 2021, salah satu yang dititik beratkan adalah memberikan edukasi dan literasi tentang kebencanaan mulai dari tingkat keluarga. Sebuah kata kunci yang perlu digaris bawahi bahwa keluarga merupakan tingkat terendah pendidikan yang perlu diperkuat, terutama penanggulangan hoaks melalui sosial media. Keluarga merupakan tataran terkecil dari sebuah negara, semua berawal dari pendidikan serta cara mendidik keluarga, bagaimana peran orang tua memberikan suri tauladan mendidik keluarganya dengan baik. Jika keluarga tersebut paham dan berhasil menerapkan edukasi dan literasi yang baik (gambar 2), maka kelak diharapkan kehidupan bernegara juga lebih penuh harapan. Satuan Tugas Covid Nasional sebagai lembaga yang ditunjuk oleh pemerintah

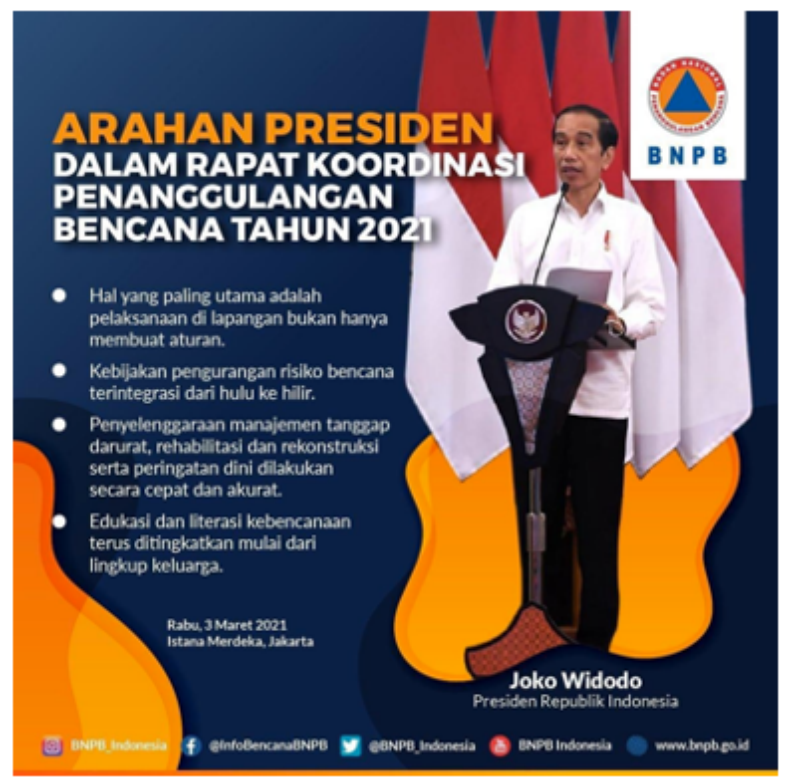

Gambar 2 Arahan Presiden Penanggulangan Bencana 2021 (sumber : BNPB)

bekerjasama dengan semua pihak, akademisi hingga influencer sosial media demi membangun edukasi ditengah masyarakat. Namun hal tersebut tidak cukup, butuh sinergi massif hingga tepat sasaran, muncullah gerakan-gerakan atau komunitas berbasis berbagai macam latar belakang ikut berperang memerangi hoaks serta memberikan edukasi di tengah pandemi melalui sosial media. Sebut saja Mafindo, sepak terjangnya tidak hanya menangkis isu-isu miring yang tidak benar tentang Covid-19, berbagai hal yang berkaitan dengan politik, sosial, budaya, agama dan lain sebagainya. MAFINDO adalah Organisasi Masyarakat Sipil anti hoaks (gambar 3), dimulai sebagai gerakan akar rumput secara daring sejak 2015. Didirikan sebagai organisasi pada 19 November 2016, dipercaya telah mempelopori banyak inisiatif anti hoaks, seperti crowdsourced hoaks busting, pendidikan literasi digital untuk publik, situs CekFakta.com, dan kampanye publik untuk meningkatkan kesadaran tentang hoaks dan bahayanya. Mafindo satu-satunya organisasi lawan hoaks yang sudah menangani 3000an kasus dan didokumentasikan rapih pada situs turnbackhoaks.id. Anita Wahid sebagai Presidium Mafindo juga bekerjasama dengan Komisi Pemilihan Umum (KPU) dan Badan Pengawas Pemilu (Bawaslu). Mafindo juga mendapatkan dukungan dari pemerintah, meskipun tidak menerima dana sepeserpun untuk menjaga kenetralan. Tujuan penting dari Mafindo selain mengedukasi masyarakat, juga mengurangi polarisasi yang mengendap berlarut-larut sejak pemilihan presiden silam, dimana berakibat memecah belah berdampak mempercayai dan mendengar kelompoknya sendiri.

Dalam menjalankan tugasnya, beberapa perjalanan yang harus dilakukan MAFINDO terdiri dari:

1. Menangani Hoaks Dunia Pendidikan

2. Menajamkan Nalar, Memperbaiki Sudut Pandang 


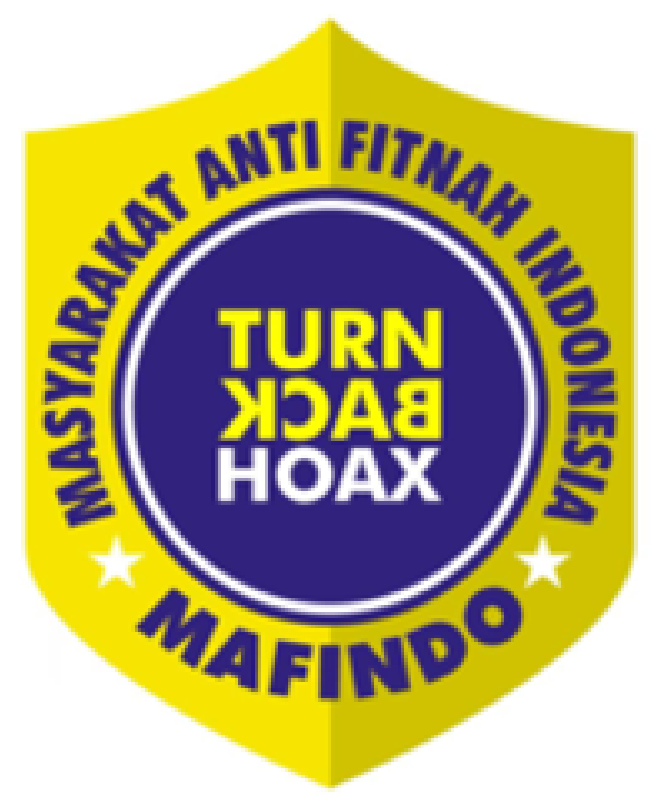

Gambar 3 Logo Mafindo (sumber : Mafindo)

\section{Dimana Bisa Cekfakta}

\section{Kelas Cekfakta}

Sebagai tenaga pendidik dan pelajar penting untuk mendapatkan informasi yang berdasarkan fakta dan jauh dari berbagai macam informasi palsu yang beredar. Terlebih lagi, dengan berbedanya cara individu untuk menangkap informasi juga sangat beragam. Oleh karena itu sebagai pengguna media sosial, baik tenaga pendidik maupun pelajar harus memproteksi diri sehingga tidak menjadi korban bias konfirmasi. Adapun berbagai macam hal yang dapat membedakan kadar bias antara lain :

1. Latar belakang

2. Daerah asal/etnis

3. Agama

4. Tingkat pendidikan

5. Pengalaman hidup

Dalam melakukan pengecekan dan pengendalian berita atau informasi yang tersebar pada Whatsapp dapat menggunakan website Rusia yaitu Yandex. Website langsung dapat mendeteksi gambar yang dimasukan dan menelusuri kebenarannya. Beberapa hal yang dapat dilalui antara lain cek sumber, berusaha berpikir kritis dan mencari klasifikasi kebenaran informasi tersebut. Selain itu, dapat juga mengecek kebenaran informasi di turnbackhoaks.id.

Dalam suatu kesempatan di TED (Technology, Entertainment, Design; 2020), Nick Pelling, seorang programmer kenamaan dari Inggris mengungkapkan bawah gamifikasi diciptakan dengan pendekatan pembelajaran menggunakan elemen-elemen dalam game/permainan bertujuan memotivasi pengguna sehingga dalam pembelajaran tersebut merasakan kenyamanan dalam mempelajari suatu masalah, membangun ketertarikan terhadap proses belajar, menangkap hal-hal yang menarik untuk didalami, serta menginspirasi. Kegembiraan yang dapat mengubah perilaku menjadi lebih baik dengan memanfaatkan elemen serta mekanisme permainan ke dalam suatu pembelajaran bertujuan meningkatkan motivasi, partisipasi dan prestasi pengguna bisa disebut sebagai upaya Gamifikasi ${ }^{3}$. Beberapa faktor yang mempengaruhi motivasi belajar dibentuk dari memahami target audiens dan konteks hingga tujuan pembelajaran. Metode ini diharapkan mampu menjadi acuan dalam mempelajari serta menangkal laju penyebaran misleading dan hoaks tentang vaksinasi Covid-19 yang terjadi disekitar kita 


\section{2 | TINJAUAN PUSTAKA}

\section{1 | Media Pembelajaran Digital}

Disrupsi pendidikan merupakan keniscayaan dan berpengaruh terhadap pembelajaran digital, seolah memaksa semua pihak beralih cepat untuk mempelajari dan memahami cara kerja pembelajaran digital ini demi mengejar ketinggalan pendidikan di era pandemi. Ketidaksiapan mental hingga infrastruktur menjadi tantangan, terutama banyaknya konten-konten distraktor yang mengganggu setiap saat melalui gawai yang digunakan setiap hari.

Media pembelajaran digital dituntut lebih efektif, sederhana, mudah dipelajari dan dipahami, tidak membutuhkan durasi panjang dan bisa diakses dimana saja. Semangat ini membuahkan pemikiran-pemikiran serta terobosan sebagai upaya agar pembelajaran digital lebih 'engaging' atau membuat pengguna menjadi ketergantungan, maka media tersebut harus lebih menarik dari konten itu sendiri. Menarik dalam hal ini adalah dari segi visual dan gamifikasi, tidak terkesan menggurui dan memiliki interaksi. Interaksi yang terjadi pada sebuah pembelajaran digital tidak harus berupa komunikasi dua arah antara pengguna dengan guru dalam arti sebenarnya, namun fitur-fitur pada pembelajaran tersebut diharapkan representasi dari guru hanya saja sudah berupa medium digital, menjadi fitur yang lebih canggih. Fitur-fitur tersebut yakni gamifikasi, dimana langkah-langkah pembelajaran yang diadaptasi dari permainan.

\section{2 | Metode Perancangan Gamifikasi}

Gamifikasi adalah jalan yang menjanjikan untuk meningkatkan keterlibatan pengguna. Akibatnya, semakin banyak pengembang aplikasi seluler yang memasukkan gamifikasi ke dalam aplikasi mereka untuk meningkatkan pengalaman pengguna. Gamifikasi diperkenalkan dalam dekade terakhir dan telah berfokus pada berbagai bidang, termasuk pendidikan. Gamifikasi, menurut Kapp, didefinisikan sebagai "The use of game design elements, game-play mechanics, aesthetics, and game thinking for non-game applications to motivate students" 4 . Meskipun belum ada istilah universal untuk Gamifikasi, kebanyakan dari mereka memiliki beberapa fitur standar. Namun, akhir-akhir ini, gamifikasi berfokus untuk melibatkan siswa secara digital, memanfaatkan platform atau aplikasi dengan penggunaan perangkat digital seperti tablet, smartphone, atau komputer. Mekanika permainan adalah bagian inti dari gamifikasi yang umumnya mewakili elemen aplikasi, yang dapat ditemukan dalam permainan seperti bercerita, lencana, poin, tangga, dan avatar ${ }^{[5}$. Gamifikasi ditandai dengan mengintegrasikan elemen desain atau format aktivitas yang terkait dengan game ke dalam konteks pendidikan, baik secara digital maupun tidak. Salah satu istilah yang sangat erat kaitannya dengan gamifikasi adalah game serius. Keduanya mencoba memanfaatkan beberapa aspek permainan untuk mencapai beberapa tujuan di luar hiburan. Perbedaan utama mereka terletak terutama pada bagaimana lingkungan mereka terkait dengan proses pendidikan. Dalam permainan yang serius, tujuan pendidikan sering tidak diketahui oleh para pemain, lingkungan belum tentu mewakili kenyataan, dan fokus utamanya adalah untuk memotivasi user untuk "memainkan" permainan tanpa membatasi jumlah mekanik permainan. Di sisi lain, dalam aplikasi gamified, semua tujuan pembelajaran selalu terlihat dan diketahui pengguna sejak awal.

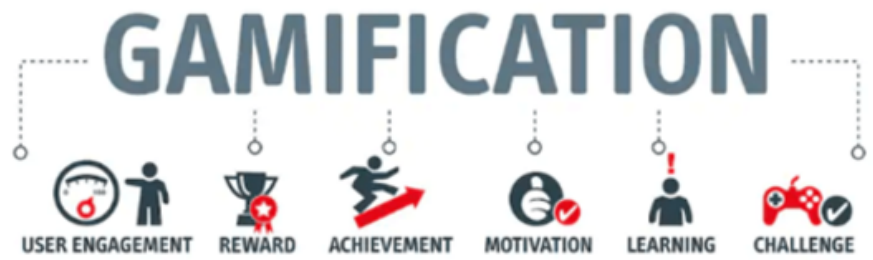

Gambar 4 Model Gamifikasi Secara Singkat (sumber : agilecrm.com)

Lingkungan mewakili masalah dan situasi dunia nyata, sementara tujuannya adalah untuk meningkatkan tingkat kesenangan, kepuasan, dan motivasi pemain yang terlibat dengan aplikasi dengan memanfaatkan sejumlah fitur permainan, seperti pada gambar 4 di mana model gamifikasi lebih menarik maka diberikan unsur-unsur seperti User Engagement, Reward, Achievement, Motivation, Learning, dan Challenge (gambar 4). Perbedaan paling mencolok antara game serius dan gamifikasi dalam pendidikan, menurut Landers, adalah proses pembelajarannya ${ }^{6}$. 
Penggunaan gamifikasi dalam pembelajaran memerlukan strategi atau model pembelajaran karena gamifikasi merupakan media pembelajaran. Media pembelajaran tidak dapat digunakan atau berdiri sendiri tanpa menggunakan strategi atau model pembelajaran. Model pembelajaran yang digunakan dalam penelitian ini adalah advance organizer.

\section{3 | METODE KEGIATAN}

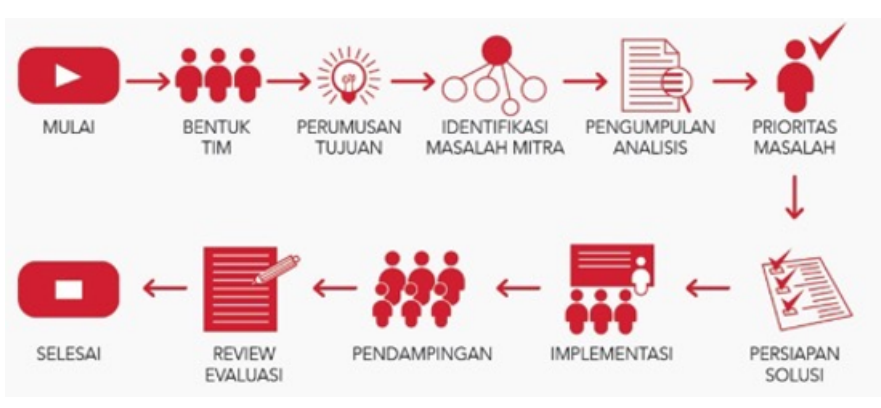

Gambar 5 Diagram Pelaksanaan

Pelakasanaan abmas basis produk berikut dimulai dengan membentuk tim yang mempunyai bidang kepakaran sesuai dengan kompetensi bidang masing-masing dosen serta mahasiswa, kemudian merumuskan masalah dan mengidentifikasi masalah dari mitra (gambar 5). Dari identifikasi tadi analisis dikumpulkan sembari memprioritaskan permasalahan. Jika masalah diprioritaskan, maka kita bisa mengambil solusi-solusi yang ditawarkan dari berbagai kemungkinan, sehingga bisa diimplementasikan kepada masalah yang dihadapi oleh mitra dan masyarakat. Namun untuk memastikan solusi dan implementasi berjalan dengan baik, dibutuhkan pendampingan yang tidak instan, artinya terdapat tahapan pendampingan hingga evaluasi, sehingga ketika solusi ini mandiri tidak lagi membutuhkan campur tangan. Kondisi ini bisa berlanjut pada tahap evaluasi, apa saja yang baik dan tidak dilanjutkan di tahapan atau kegiatan berikutnya.

\section{1 | Metode Gamifikasi}

Adapun beberapa hal yang menjadi landasan pembuatan game ini, berdasarkan observasi dan masukan dari mitra serta merujuk pada sesi-sesi penanggulanan hoaks, antara lain bahwa hoaks itu mempunyai karakteristik :

1. Menciptakan kecemasan, kebencian dan permusuhan

2. Berasal dari sumber yang tidak jelas dan susah dipertanggungjawabkan

3. Kontennya cenderung sepihak, tidak netral

4. Mencantumkan narasumber, idol, atau nama tokoh, sehingga kita terkecoh

5. Memanfaatkan fanatism, misalnya ideologi, agama, politik, dll

6. Judulnya clickbait, isinya tidak sesuai isi

7. Meminta share, like dan comment, agar tersebar luar

8. Menggunakan argument data palsu agar mudah dipercaya

9. Tidak ada kejelasan nama media, author, reporter atau siapa yang incharge

10. Menggunakan konten, media, foto lama yang tidak relevan, untuk menggiring opini

Dari beberapa poin diatas, ada beberapa cara penanggulangan yang bisa dilakukan, antara lain :

1. Media hoaks buster sebisanya disosialisasikan lebih banyak kepada anak muda khususnya masih sekolah 
2. Adanya perwakilan yang bisa mensosialisasikan, mungkin seperti influencer dikalangan sendiri agar menarik dan ikut tertarik mensosialisasikan

3. Media hoaks buster dikemas dengan mudah dan friendly, khususnya untuk segmen yang sudah berumur

4. Penggunaan bahasa yang jelas lugas tepat sasaran

5. Memberikan peringatan agar tidak mudah menelan secara langsung informasi yang tersebar

6. Selalu periksa fakta terhadap informasi yang beredar

7. Tidak terlalu ribet atau banyak system sehingga malah masyarakat/pengguna enggan ikut berperan dalam penanggulangan hoaks

Dari uraian diatas, masyarakat tidak hanya diminta menggunakan game yang bersifat menantang (challenging), memberantas hoaks, atau diberikan tebak-tebakan ini hoaks atau bukan? Setidaknya ada salah satu referensi permaianan disebut getbadnews.com, dimana pada game ini kita diajak terlibat membuat hoaks, dari situ sebenarnya pemain yang tidak berempati akan terus menerus atau sengaja membuat hoaks, bagi yang benar-benar serius, atau berempati akan berusaha meminimalisir hoaks yang dibuat. Goal-nya memang role play, memahami cara membuat hoaks, terlibat menjadi produsen hoaks.

\section{2 | Tahap Perancangan}

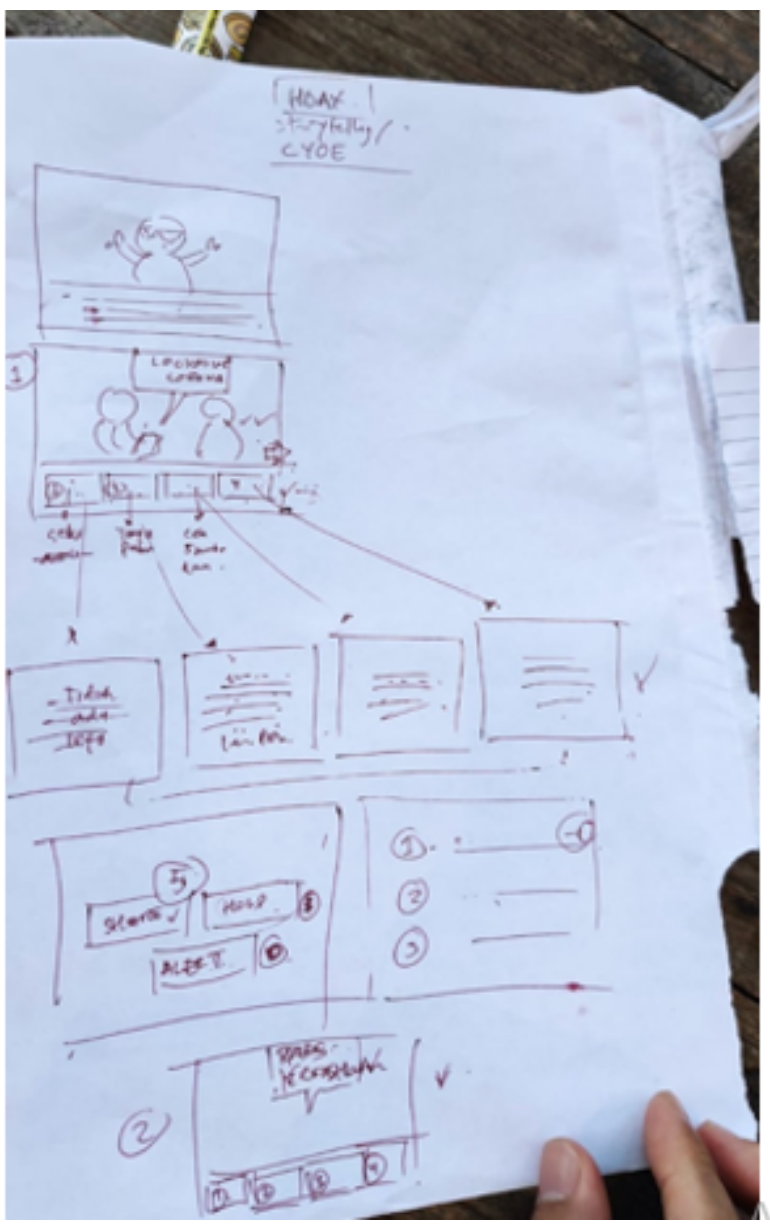

Gambar 6 Rough Sketch Storyline 
Tabel 1 List Dialog Level

\begin{tabular}{|c|c|c|c|c|c|c|c|c|c|}
\hline \multirow{2}{*}{$\begin{array}{l}\text { NO. } \\
\text { INFO }\end{array}$} & \multirow[t]{2}{*}{ URAIAN INFO } & \multicolumn{4}{|c|}{ MENU FAKTA } & \multicolumn{4}{|c|}{ SCORE MENU SHARE } \\
\hline & & Info Eakta & Fakta Pendapat & Eakta Qpini & Eakta sosmed & Share Info & Piam Saia! & Share Eakta & KESIMPULAN \\
\hline 1 & 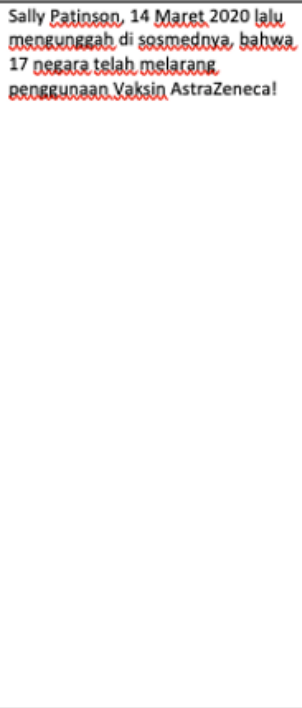 & 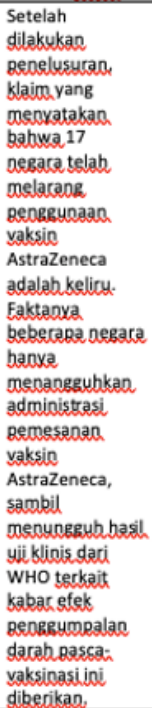 & 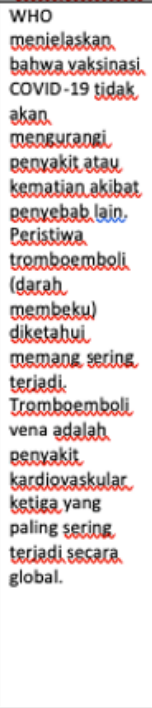 & $\begin{array}{l}\text { TIDAK ADA } \\
\text { INFO }\end{array}$ & $\begin{array}{l}\text { TIDAK ADA } \\
\text { INFO }\end{array}$ & 0 & 5 & 10 & $\begin{array}{l}\text { Info tersebut } \\
\text { adalab hoax, } \\
\text { karenaitu } \\
\text { tindakan va } \\
\text { paling tepat } \\
\text { adalah Share } \\
\text { Eakta. }\end{array}$ \\
\hline
\end{tabular}

Perancangan yang dibuat berdasarkan hasil data yang kumpulkan oleh mitra dalam hal ini Mafindo, kemudian diimplementasikan pada pembuatan storyline untuk memudahkan alur dari permainan (gambar 6). Kemudian dilanjutkan dengan pembuatan konten dan detail permainan yang dijabarkan sebagai berikut:

\subsection{Laman Opening}

Selamat datang di Pramana Sahwahita (gambar 7), sebuah wahana edukasi yang akan melatih lalu membawa anda memahami serta mencari isu-isu hoaks dan misleading pada pemberitaan Vaksin Covid-19.

Pada wahana ini anda diminta untuk menelaah beberapa dialog isu tentang vaksin covid-19 lalu segera putuskan, pada akhir pertanyaan terdapat rentang score yang akan menentukan posisi anda ada dimana. Pramana Sahwahita, merupakan bahasa Sanskerta, berarti mencari pengetahuan untuk kebenaran yang manfaatnya bisa kita rasakan untuk kita semua. Harapannya permainan ini nantinya tidak hanya permainan bertema hoaks covid-19 atau vaksin namun juga isu hoaks lainnya.

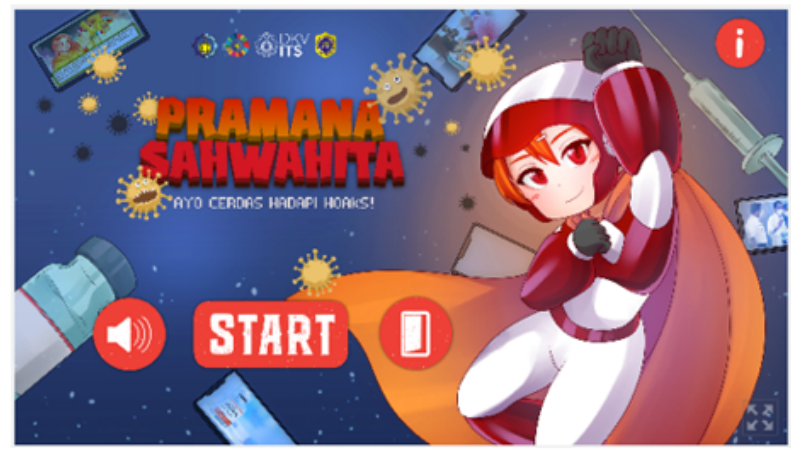

Gambar 7 Laman opening 


\section{4 | Laman Leveling}

Prototype permainan bergenre visual novel ini terdiri dari 15 level dialog berita (gambar 9) yang berisi informasi tentang hoaks vaksinasi dan konten benar secara fakta. Dialog-dialog tersebut diambil dari bank data Mafindo yang kemudian diolah dan disederhanakan (lihat tabel 1).

Pada 15 level atau dialog tersebut terdiri dari informasi berupa teks yang diambil dari berita berdasarkan fakta, opini dan hoaks atau misleading. Ada beberapa jenis informasi yaitu info berbasis data, tanggapan dari ahli, dan contoh kasus.

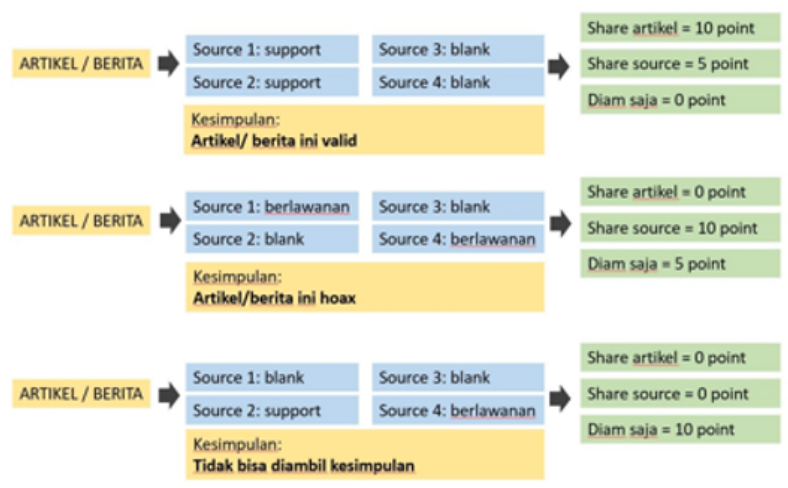

Gambar 8 Hirarki Leveling

Info berita tersebut harus dikonfirmasi dengan memilih informasi-informasi tambahan yang isinya bisa saja berlawanan, support atau bahkan tidak ada info atau blank, sehingga user harus memutuskan mana yang terbaik. Penjelasan kondisi membagikan informasi tersebut dari gambar 8 adalah sebagai berikut :

1. "Share bahwa itu hoaks"; dimana point tertinggi hanya ketika informasi / konfirmasi menyebutkan fakta yg berlawanan dengan berita awal

2. "Tidak melakukan apa-apa" dimana point tertinggi ketika kita menemukan fakta yg berlawanan sehingga kita tidak dapat memutuskan itu hoaks / bukan

3. "Share berita awal" dimana point tertinggi ketika informasi/konfirmasi menyebutkan fakta yang mendukung berita tersebut
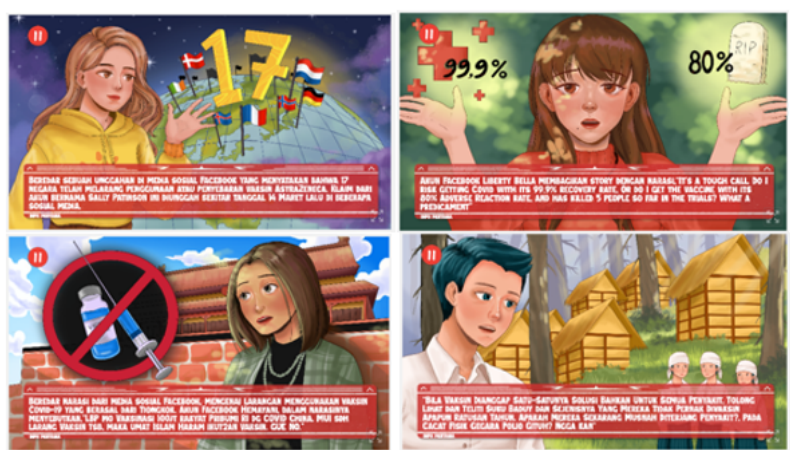

Gambar 9 Contoh Laman Leveling 


\section{5 | Laman Penilaian/Scoring}

Jika user membagikan artikel atau berita berdasarkan fakta maka mendapatkan nilai 10 point, jika membagikan hoaks maka mendapatkan angka 0 , dan yang jika skeptis atau diam saja mendapatkan 5 point saja. Score atau point akan diakumulasi dan dihitung diakhir level, user akan mendapatkan pengkategorian nilai sebagai berikut (gambar 8) :

76-100 : Smart Netizen!

51-75 : Good Netizen!

26-50 : Susceptible Netizen!

0-25 : Agen Hoaks!

\section{4 | KESIMPULAN}

Pengabdian masyarakat berbasis produk berupa perancangan prototype permainan digital berbasis web dengan tema hoaks anti vaksin ini sebagai sarana edukasi kepada skup keluarga dimana merupakan bagian terkecil dari masyarakat. Harapannya prototype ini menjadi media baru yang bisa digunakan menjadi sarana edukasi mitra untuk menanggulangi hoaks dan mendukung keberhasilan program pemerintah yaitu vaksin covid-19 yang hingga saat ini masih berlangsung. Pengabdian masyarakat ini dibantu oleh beberapa mahasiswa Kuliah Kerja Nyata Abmas berbasis produk yang terjun langsung mengobservasi kontenkonten hoaks dan hasil observasi tersebut diadaptasi menjadi prototype permainan ini. Prototype permainan ini bergenre visual novel yang terdiri dari 15 level informasi berita tentang vaksin beserta konten-konten pembandingnya. Dari level-level tersebut, user diharapkan bisa membedakan konten yang berdasarkan fakta atau hoaks, user secara langsung dipaksa untuk membaca, menelaah dan berpikir sebelum membagikan informasi, jika hal tersebut sudah diputuskan maka akan mendapatkan reward. Langkah-langkah pada prototype ini merupakan gamifikasi sederhana yang secara tidak sadar sering terjadi di aktifitas seharihari dalam mengakses sosial media. Dengan desain ilustrasi, layout menarik, mekanik permainan dan audio yang immersive, user seolah-oleh bermain sembari belajar, tidak menggurui, diakhir permainan dapat segera diketahui nilai dan kategori yang layak disandang.

\section{Referensi}

1. Restiviani Y, Putra N, Irwansyah SR, Zahara R. Filtering Before Sharing Hoax Covid-19 Anticipation Efforts Social Media, Islamic Communication Ethics, And Public Responsibility Perspective. Asian Social Science and Humanities Research Journal (ASHREJ) 2021;3(1):10-21.

2. Gustomy R. Pandemi ke infodemi: Polarisasi politik dalam wacana Covid-19 pengguna Twitter. JIIP: Jurnal Ilmiah Ilmu Pemerintahan 2020;5(2):190-205.

3. Nabilah BF, et al. The effect of mixed gamification and achievement motivation on concept comprehension and creative thinking skills in learning science. Psychology and Education Journal 2021;58(1):5139-5152.

4. Díaz-Ramírez J. Gamification in engineering education-An empirical assessment on learning and game performance. Heliyon 2020;6(9):e04972.

5. Kalogiannakis M, Papadakis S, Zourmpakis AI. Gamification in science education. A systematic review of the literature. Education Sciences 2021;11(1):22.

6. Aini Q, Budiarto M, Putra POH, Santoso NPL. Gamification-based The Kampus Merdeka Learning in 4.0 era. IJCCS (Indonesian Journal of Computing and Cybernetics Systems) 2021;15(1):31-42.

Cara mengutip artikel ini: Ramadhani, N. Alamin, R.Y. Darmawati, N.O. Prasetyo, D. Dwitasari, P. Kusumawardani, R.P. , (2022), Gamifikasi Upaya Menangkal Hoaks Terhadap Informasi Vaksinasi Covid-19 di Social Media dalam Scope Keluarga, Sewagati: Jurnal Pengabdian Kepada Masyarakat, 6(1):51-60. 